\title{
PENGARUH PEMASARAN HIJAU, CITRA MEREK DAN PENGETAHUAN LINGKUNGAN TERHADAP KEPUTUSAN PEMBELIAN
}

\author{
Yuaniko Paramitra *) \\ 1) Dosen Program Studi Manajemen FE UNKRIS \\ Alamat: Kampus UNKRIS, Jatiwaringin Jakarta Timur \\ Email : nicoyp@unkris.ac.id
}

\begin{abstract}
The purpose of this study is to analyze the effect of green marketing on green purchase behavior. The research was conducted in an explanatory, and using quantitative. The study sample was 66 of the participants in the environmental care activities. The sampling technique used in this study is purposive sampling. The results showed that the variables of green marketing, brand image and environmental knowledge simultaneously and partially had a positive effect on green purchase behavior. While brand image and environmental knowledge variables can increase the influence of green marketing on purchasing decisions.
\end{abstract}

Keywords : Green marketing, brand image, environmental knowledge and green purchase behavior

\section{PENDAHULUAN}

Pada saat ini sudah sangat banyak iklan yang beredar di masyarakat, perusahaan perusahaan pun mulai mengubah strategi marketing mereka. Ada yang dengan cara menggabungkan antara entertainment dengan komunikasi marketing diantaranya melalui advergames (Paramitra dan Aruan, 2017), ada pula yang melakukan pendekatan melalui kepedulian terhadap lingkungan hidup atau green marketing (Situmorang, 2011 ; Kotler dan Armstrong, 1991).

Semakin meningkatnya kesadaran masyarakat dunia akan lingkungan dan pemanasan global membuat mereka lebih berhati hati dalam menggunakan atau mengkonsumsi barang, terutama barang barang yang dapat menambah kerusakan lingkungan hidup. Menurut UU No. 23 Tahun 1997, lingkungan hidup adalah kesatuan ruang dengan semua benda dan kesatuan makhluk hidup termasuk di dalamnya manusia dan perilakunya yang melangsungkan perikehidupan dan kesejahteraan manusia serta makhluk hidup lainnya.

Perubahan pola konsumsi masyarakat ini mulai dimanfaatkan oleh para produsen yang mulai beralih menggunakan bahan baku yang ramah lingkungan, dan lebih luas lagi tidak hanya terbatas pada material bahan baku produknya saja, namun juga pada kemasan, label, karton pembungkus dan lain lain (Situmorang, 2011). Salah satu contohnya adalah produsen minuman teh sosro siap minum yang mengemasnya menjadi teh dalam botol kaca atau RGB (Returnable Glass Bottling), yang dapat mengurangi penggunaan plastik karena bahan plastik tidak ramah lingkungan. Teh dalam kemasan botol kaca sosro ini bahkan sudah diperkenalkan semenjak tahun 1969

(http://www.sinarsosro.id/about/cor porate-profile) dengan maksud dan tujuan menciptakan produk yang berkualitas baik, sehat, aman dan ramah lingkungan. Contoh lainnya adalah policy atau 
kebijakan yang baru diterapkan oleh beberapa restoran fast food untuk mengurangi atau tidak menyediakan sedotan dalam dispenser demi untuk mengurangi sampah plastik. Bahkan dari industry otomotif pun tidak ingin ketinggalan dengan mengembangkan mobil - mobil berbahan bakar listrik atau disebut dengan hybrid, termasuk di Indonesia, bahkan pemerintah melalui KEMENPERIN berupaya untuk mendorong produksi mobil hybrid dan mobil listrik (http://www.kemenperin.go.id/artikel/180 68/Kemenperin-Dorong-Produksi-MobilHybrid-dan-Listrik).

Konsep pemasaran produk dengan menggunakan bahan - bahan baku ataupun kebijakan yang ramah lingkungan dapat disebut dengan green marketing (Situmorang, 2011). Tujuan green marketing diantaranya adalah mengembangkan produk yang lebih aman dan ramah lingkungan, meminimalkan limbah bahan baku dan energi, mengurangi kewajiban akan masalah lingkungan hidup dan meningkatkan efektifitas biaya dengan memenuhi peraturan lingkungan hidup agar dikenal sebagai perusahaan yang baik (Heizer dan Render, 2006).

Berdasarkan paparan tersebut salah satu tujuan utama dari green marketing ini adalah menciptakan citra merek yang baik. Citra merek adalah persepsi dari pelanggan yang berepengaruh secara positif terhadap produsen atau produk - produknya, sehingga dapat menyebabkan terjadinya keputusan pembelian produk oleh konsumen. Hal ini dikarenakan citra perusahaan yang positif cenderung akan memicu pembeli atau konsumen untuk membeli produk tersebut (Sutisna dan Pawitra, 2001).

Namun berdasarkan temuan Grocery Manufacturer Association (GMA), ternyata para konsumen atau pengguna produk ramah lingkungan masih dalam tahap pembelajaran. Sehingga konsumen masih kurang memahami tentang manfaat sosial dan manfaat lingkungan dari berbelanja produk - produk ramah lingkungan atau produk hijau (green product) (GMA,2009). Oleh karena itu sangat penting bagi produsen untuk dapat memberikan edukasi tentang pengetahuan lingkungan (environtmental knowledge) dan dampak dari mengkonsumsi produk hijau ini.

Tujuan dari penelitian ini adalah untuk melihat apakah pengetahuan lingkungan dan citra merek dapat menjadi variabel dalam variabel yang memediasi green marketing dan keputusan pembelian produk ramah lingkungan (green product).

\section{LANDASAN TEORI}

\section{Pemasaran Hijau}

Menurut Simamora (2011) dan Polonsky (2001) penggunaan istilah pesaran hijau (green marketing) pertama kali diperkenalkan akhir tahun 1970, yaitu oleh American Marketing Association (AMA) yang mendefinisikan pemasaran hijau yaitu,"green marketing is the marketing of products that are presumed to be environmentally safe. Thus green marketing incorporates a broad range of activities, including product modification, change to the production process, packaging changes, as well as modifying advertising."

Sementara definisi menurut Lampe (1995), "green marketing is defined as the marketing response to the environmental effects of the design, production, packaging, labeling, use and disposal of goods and services". Selain itu ada juga definisi green marketing menurut Kotler dan Armstrong (1991) "green marketing as the production of security products that meet the environmental standards, with recyclable and reusable packaging, 
with better pollution control methods and operate energy efficiently".

Jadi sebenarnya apa yang didefinisikan tentang green marketing sangatlah luas dan mencakup banyak aspek bisa dari sisi proses produksi, packaging dan label yang dapat di daur ulang dan di reuse, termasuk juga pengelolaan limbah yang ramah lingkungan dengan tujuan untuk menjaga kelestarian lingkungan.

Tujuan utama dari green marketing adalah untuk meraih pangsa pasar yang lebih luas pasar yang terus tumbuh dari konsumen yang peduli lingkungan. Menurut Simamora (2011) Pasar produk hijau ditaksir mencapai sekitar 52 juta kepala keluarga di Amerika Serikat tahun 1995 dan terus berkembang hingga kini. Tidak hanya di Amerika saja namun gerakan ini semakin meluas terjadi Jerman $88 \%$ konsumen menyatakan bahwa mereka mulai beralih ke produk produk yang lebih hijau. Karena perkembangan jumlah konsumen inilah banyak sekali produsen yang melakukan green marketing dengan maksud untuk mencapai keunggulan bersaing yang berkelanjutan (Oyewole, 2001).

\section{Citra Merek}

Kotler dan Keller (2009:403) mendefinisikan, citra merek (brand image) sebagai persepsi dan keteguhan yang dipegang oleh pelanggan, seperti yang tercermin dalam asosiasi yang tertanam pada ingatan konsumen. Tjiptono (2005), citra merek atau brand image merupakan deskripsi tentang asosiasi dan keyakinan pelanggan terhadap suatu merek.

Citra merek adalah persepsi dari pelanggan yang berepengaruh secara positif terhadap produsen atau produk produknya, sehingga dapat menyebabkan terjadinya keputusan pembelian produk oleh konsumen. Hal ini dikarenakan citra perusahaan yang positif cenderung akan memicu pembeli atau konsumen untuk membeli produk tersebut (Sutisna dan Pawitra, 2001). Menurut Pujari (2003), green marketing yang dilakukan oleh produsen berdampak positif bagi perusahaan, diantaranya peningkatan penjualan, meningkatkan kemampuan bersaing perusahaan, memperbaiki atau meningkatkan citra brand atau perusahaan.

Menurut Kurniawati (2011) dan Agustin (2009) yang melakukan penelitian tentang green marketing, mendapatkan hasil bahwa produsen atau perusahaan yang melakukan pemasaran hijau atau green marketing akan sangat berpengaruh terhadap citra merek.

Berdasarkan beberapa hasil penelitian tersebut, strategi green marketing akan dapat meningkatkan citra merek yang akan berujung terhadap peningkatan minat beli dan keputusan pembelian terhadap produk hijau (green product).

\section{Pengetahuan Lingkungan}

Pengetahuan lingkungan dapat didefinisikan sebagai pengetahuan tentang lingkungan hidup. Beberapa studi sudah pernah dilakukan untuk melihat hubungan antara pengetahuan lingkungan dengan minat beli produk hijau atau produk ramah lingkungan. Haron, Paim and Yahaya (2005) melakukan penelitian tentang pengetahuan lingkungan di Malaysia, dan membagi pengetahuan ini menjadi empat tipe yaitu: besik pengetahuan lingkungan, pengetahuan tentang permasalahan lingkungan di Malaysia, pengetahuan tentang item yang dapat didaur ulang dan pengetahuan tentang konsep yang terkait dengan lingkungan hidup.

Demikian pula dengan hasil penelitian Azizan dan suki (2013) yang menemukan bahwa pengetahuan lingkungan merupakan faktor yang sangat berpengaruh bagi konsumen untuk melakukan keputusan pembelian produk - produk hijau atau produk ramah 
lingkungan. Berdasarkan hasil penelitian tersebut maka pengetahuan tentang lingkungan yang dimiliki oleh calon konsumen sangat penting dalam melakukan pembelian terhadap produk ramah lingkungan.

\section{Keputusan Pembelian Produk Hijau}

Kotler dan Keller (2009) menyatakan proses keputusan pembelian ada lima tahapan, yaitu: pengenalan masalah, pencarian informasi, evaluasi alternatif, keputusan pembelian, dan pasca pembelian. Pada tahap keputusan pembelian, konsumen benar-benar melakukan pembelian. Swastha dan Handoko (2013) mengatakan bahwa sebuah keputusan untuk membeli yang diambil oleh konsumen adalah kumpulan dari sejumlah keputusan. Setiap keputusan pembelian memiliki tujuh struktur komponen, diantaranya: keputusan tentang jenis produk, bentuk produk, merek, penjualnya, jumlah produk, waktu pembelian, dan cara pembayaran. Oleh karena itu selain keunggulan produk dan citra merek, produsen atau perusahaan harus dapat memberikan kenyamanan bertransaksi konsumen.

\section{METODE PENELITIAN}

$\begin{array}{rrr}\text { Penelitian } & \text { ini } & \text { merupakan } \\ \text { explanatory } & \text { dengan } & \text { pendekatan }\end{array}$ kuantitatif. Penelitian ini dilakukan di acara "peduli lngkungan hidup : Penerapan reduce, reuse, recycle". Harapan peneliti menggunakan acara peduli lingkungan hidup ini adalah agar responden yang diambil dalam penelitian ini homogen, memiliki pengetahuan yang tinggi tentang lingkungan. Metode pengumpulan data pada penelitian ini menggunakan kuesioner. Skala pengukuran yang digunakan dalam kuesioner tersebut mempunyai skor antara 1-5, semakin ke 1 maka jawaban semakin tidak setuju hingga seterusnya ke 5 berarti jawaban sangat setuju. Sample diambil dengan metode purposive sampling dengan karakteristik menggunakan produk tisu Tessa. Adapun jumlah responden yang diambil adalah sebanyak 66 orang responden.

Adapun penggunaan produk tisu Tessa dalam penelitian ini adalah karena tissue Tessa merupakan satu-satunya produk tisu di Indonesia yang telah menggunakan logo Forest Stewardship Council (FSC) pada kemasannya. Membuktikan bahwa produk Tessa telah berhasil memenuhi sertifikasi produk berbahan baku ramah lingkungan yang diakui secara internasional.

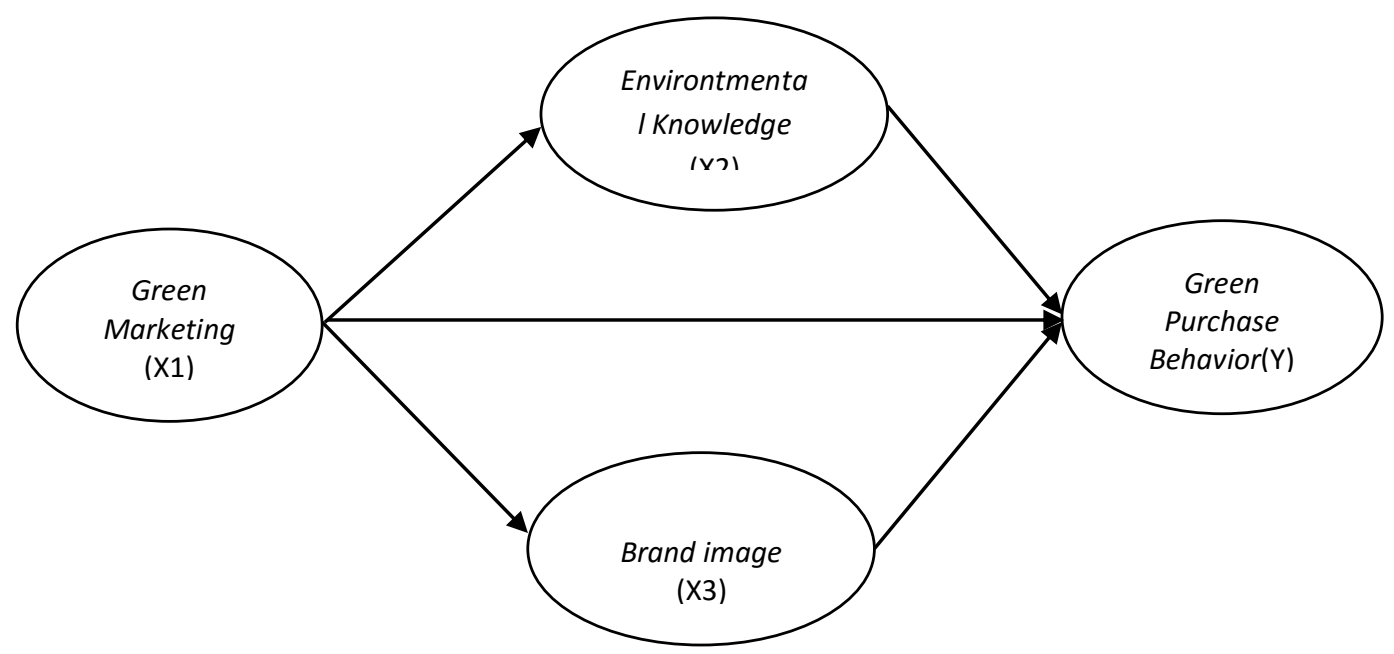

Gambar 1. Kerangka Penelitian 


\section{PEMBAHASAN HASIL PENELITIAN}

Uji Validitas

Fungsi dari uji validitas adalah untuk menguji masing-masing variabel penelitian, dimana keseluruhan variabel penelitian memuat 31 pernyataan yang dijawab oleh 66 orang responden. Berdasarkan analisis yang telah dilakukan, maka hasil pengujian validitas dapat ditunjukkan pada Tabel dibawah ini

Tabel 1. Hasil Uji Validitas

\begin{tabular}{|c|c|c|c|c|}
\hline Variabel & Pernyataan & R hitung & $\begin{array}{l}\text { Nilai } \\
\text { Kritis }\end{array}$ & Keterangan \\
\hline \multirow{8}{*}{$\begin{array}{c}\text { Green } \\
\text { Marketing } \\
\text { (X1) }\end{array}$} & Green Marketing 1 & 0,582 & 0,3 & Valid \\
\hline & Green Marketing 2 & 0,775 & 0,3 & Valid \\
\hline & Green Marketing 3 & 0,898 & 0,3 & Valid \\
\hline & Green Marketing 4 & 0,880 & 0,3 & Valid \\
\hline & Green Marketing 5 & 0,872 & 0,3 & Valid \\
\hline & Green Marketing 6 & 0,728 & 0,3 & Valid \\
\hline & Green Marketing 7 & 0,723 & 0,3 & Valid \\
\hline & Green Marketing 8 & 0,667 & 0,3 & Valid \\
\hline \multirow{8}{*}{$\begin{array}{l}\text { Environtmental } \\
\text { Knowledge } \\
\text { (X2) }\end{array}$} & Environmental Knowledge 1 & 0,843 & 0,3 & Valid \\
\hline & Environmental Knowledge 2 & 0,853 & 0,3 & Valid \\
\hline & Environmental Knowledge 3 & 0,724 & 0,3 & Valid \\
\hline & Environmental Knowledge 4 & 0,887 & 0,3 & Valid \\
\hline & Environmental Knowledge 5 & 0,864 & 0,3 & Valid \\
\hline & Environmental Knowledge 6 & 0,789 & 0,3 & Valid \\
\hline & Environmental Knowledge 7 & 0,757 & 0,3 & Valid \\
\hline & Environmental Knowledge 8 & 0,781 & 0,3 & Valid \\
\hline \multirow{7}{*}{$\begin{array}{l}\text { Brand Image } \\
\text { (X3) }\end{array}$} & Brand Image 1 & 0,941 & 0,3 & Valid \\
\hline & Brand Image 2 & 0,955 & 0,3 & Valid \\
\hline & Brand Image 3 & 0,947 & 0,3 & Valid \\
\hline & Brand Image 4 & 0,941 & 0,3 & Valid \\
\hline & Brand Image 5 & 0,868 & 0,3 & Valid \\
\hline & Brand Image 6 & 0,955 & 0,3 & Valid \\
\hline & Brand Image 7 & 0,878 & 0,3 & Valid \\
\hline \multirow{8}{*}{$\begin{array}{l}\text { Green Purchase } \\
\text { Behavior } \\
\text { (Y) }\end{array}$} & Green Purchase Behavior 1 & 0,897 & 0,3 & Valid \\
\hline & Green Purchase Behavior 2 & 0,972 & 0,3 & Valid \\
\hline & Green Purchase Behavior 3 & 0,945 & 0,3 & Valid \\
\hline & Green Purchase Behavior 4 & 0,917 & 0,3 & Valid \\
\hline & Green Purchase Behavior 5 & 0,939 & 0,3 & Valid \\
\hline & Green Purchase Behavior 6 & 0,968 & 0,3 & Valid \\
\hline & Green Purchase Behavior 7 & 0,936 & 0,3 & Valid \\
\hline & Green Purchase Behavior 8 & 0,935 & 0,3 & Valid \\
\hline
\end{tabular}

Data Primer diolah Tahun 2016 
Berdasarkan pada Tabel 1 diketahui bahwa nilai korelasi antara item dengan total lebih besar dari nilai 0,3 . Hal ini berarti seluruh item pernyataan yang diajukan bersifat valid sehingga dapat digunakan untuk analisis selanjutnya.

\section{Uji Reliabilitas}

Uji reliabilitas digunakan untuk mengetahui sejauh mana hasil pengukurannya dapat diandalkan dan konsisten. Berdasarkan analisis yang telah dilakukan, maka hasil pengujian validitas dapat ditunjukkan pada Tabel dibawah ini

Tabel 2. Hasil Reliabilitas

\begin{tabular}{lcccc}
\hline \multicolumn{1}{c}{ Variabel } & $\begin{array}{c}\text { Cronbach's } \\
\text { Alpha }\end{array}$ & Nilai Kritis & $\begin{array}{c}\text { N of } \\
\text { items }\end{array}$ & Keterangan \\
\hline Green Marketing (X1) & 0,932 & 0,600 & 8 & Reliabel \\
Environmental Knowledge (X2) & 0,949 & 0,600 & 8 & Reliabel \\
Brand image / Citra merek (X3) & 0,981 & 0,600 & 7 & Reliabel \\
Green Purchase Behavior (Y) & 0,986 & 0,600 & 8 & Reliabel \\
\hline
\end{tabular}

Data Primer diolah Tahun 2016

\section{Uji Hipotesis}

Tabel 3. Uji Kausalitas Variabel Penelitian dan Uji Hipotesis

\begin{tabular}{|c|c|c|c|c|c|c|c|c|c|c|c|}
\hline \multirow{2}{*}{$\begin{array}{l}\text { Variabel } \\
\text { Dependen }\end{array}$} & \multirow{2}{*}{ Konstanta } & \multicolumn{6}{|c|}{ Variabel Independen } & \multicolumn{2}{|c|}{ F-Hitung } & \multirow{2}{*}{$\begin{array}{c}\text { Nilai } \\
\mathbf{t}\end{array}$} & \multirow{2}{*}{$\mathbf{R}^{2}$} \\
\hline & & $\mathbf{X 1}$ & Prob & $\mathrm{X} 2$ & Prob & $\mathbf{X 3}$ & Prob & Nilai & Prob & & \\
\hline Green & 19,583 & ,353* & ,004 & & & & & & & 3,014 & ,124 \\
\hline Purchase & 12,452 & & & ,667* & ,002 & & & & & 3,159 & 135 \\
\hline Behavior & 16,811 & & & & & ,618* & ,000 & & & 3,676 & ,174 \\
\hline (Y) & 16,562 &, $186^{*}$ & ,026 & ,236* & ,016 & - & - & 5,651 & ,006 & & ,152 \\
\hline
\end{tabular}

Keterangan : X1 = Green Marketing ; X2 = Environmental Knowledge ; X3 = Brand image/Citra merek ; *p-value (nilai probabilitas) $<0,05$

Data Primer diolah Tahun 2016

Analisis Pengaruh Pemasaran Hijau, Pengetahuan Lingkungan dan Citra Merek secara simultan terhadap Keputusan Pembelian Produk Hijau

Berdasarkan perhitungan Tabel 3 diketahui bahwa nilai $\mathrm{F}$ hitungnya sebesar 5.651 dan nilai signifikansi sebesar 0,006. Nilai ini lebih kecil dari 0,05 . Hal ini berarti bahwa variabel pemasaran hijau, pengetahuan lingkungan dan citra merek berpengaruh terhadap keputusan pembelian produk hijau. Sedangkan besarnya pengaruh variabel independen $\left(\mathrm{X}_{1}, \mathrm{X}_{2}\right.$ dan $\left.\mathrm{X}_{3}\right)$ terhadap variabel dependen dapat dilihat dari nilai $r$ kuadratnya yaitu senilai 0,152 , ini berarti bahwa variabel pemasaran hijau, pengetahuan lingkungan dan citra merek memiliki pengaruh terhadap keputusan pembelian produk hijau sebesar 15,2\%, sedangkan sisanya dipengaruhi variabel lain yang tidak dimasukkan kedalam model persamaan.

Analisis Pengaruh Pemasaran Hijau, Pengetahuan Lingkungan dan Citra Merek secara parsial terhadap Keputusan Pembelian Produk Hijau

Pada Tabel 3 dapat diketahui nilai koefisien pemasaran hijau sebesar 0,353. Dan besarnya nilai t adalah 3,014. Nilai signifikansi sebesar 0,04. Nilai signifikansi ini lebih kecil dibandingkan dengan 0,05. Hal ini berarti bahwa variabel pemasaran hijau memiliki pengaruh terhadap keputusan pembelian 
produk hijau secara parsial. Pada Tabel 3 tersebut juga dapat diketahui nilai $r$ kuadrat pemasaran hijau sebesar 0,124. ini berarti bahwa variabel pemasaran hijau memiliki pengaruh terhadap keputusan pembelian produk hijau sebesar $12,4 \%$ dan sisanya dipengaruhi oleh variabel lain.

Untuk pengetahuan lingkungan memiliki nilai koefisien sebesar 0,667. Dan besarnya nilai $\mathrm{t}$ adalah 3,159. Dengan nilai signifikansi sebesar 0,002 . Nilai signifikansi ini lebih kecil dibandingkan dengan 0,05 . Hal ini berarti bahwa variabel pengetahuan lingkungan memiliki pengaruh terhadap keputusan pembelian produk hijau secara parsial. Pada Tabel 3 tersebut juga dapat diketahui nilai $r$ kuadrat pengetahuan lingkungan sebesar 0,135. ini berarti bahwa variabel pengetahuan lingkungan memiliki pengaruh terhadap keputusan pembelian produk hijau sebesar sebesar $13,5 \%$ dan sisanya dipengaruhi oleh variabel lain.

Untuk citra merek memiliki nilai koefisien sebesar 0,618. Nilai t sebesar 3,676. Nilai signifikansi sebesar 0,000 . Nilai signifikansi ini lebih kecil dibandingkan dengan 0,05 . Hal ini berarti bahwa variabel citra merek memiliki pengaruh terhadap keputusan pembelian produk hijau secara parsial. Berdasarkan pada Tabel di atas dapat diketahui nilai $r$ kuadrat citra merek sebesar 0,174 . Hal ini berarti pengaruh variabel citra merek terhadap keputusan pembelian produk hijau sebesar $17,4 \%$ dan sisanya dipengaruhi oleh variabel lain yang tidak dimasukkan kedalam model persamaan.

\section{Analisis Citra Merek sebagai variabel moderasi dari Pemasaran Hijau terhadap Keputusan Pembelian Produk Hijau}

Berdasarkan pada analisis jalur dari ketiga variabel yang akan diuji (Gambar 2). diketahui bahwa pengaruh pemaaran hijau terhadap keputusan pembelian produk hijau adalah 0,353. Sedangkan pengaruh pemaaran hijau terhadap keputusan pembelian produk hijau melalui citra merek adalah 0,736 X 0,618 $=0,455$. Dalam hal ini pengaruh tidak langsung lebih besar dibandingkan pengaruh langsung sehingga dapat dikatakan bahwa variabel citra merek dapat meningkatkan pengaruh pemasaran hijau terhadap keputusan pembelian prouk hijau adalah variabel intervening dalam hubungan pengaruh pemasaran hijau terhadap keputusan pembelian prouk hijau.

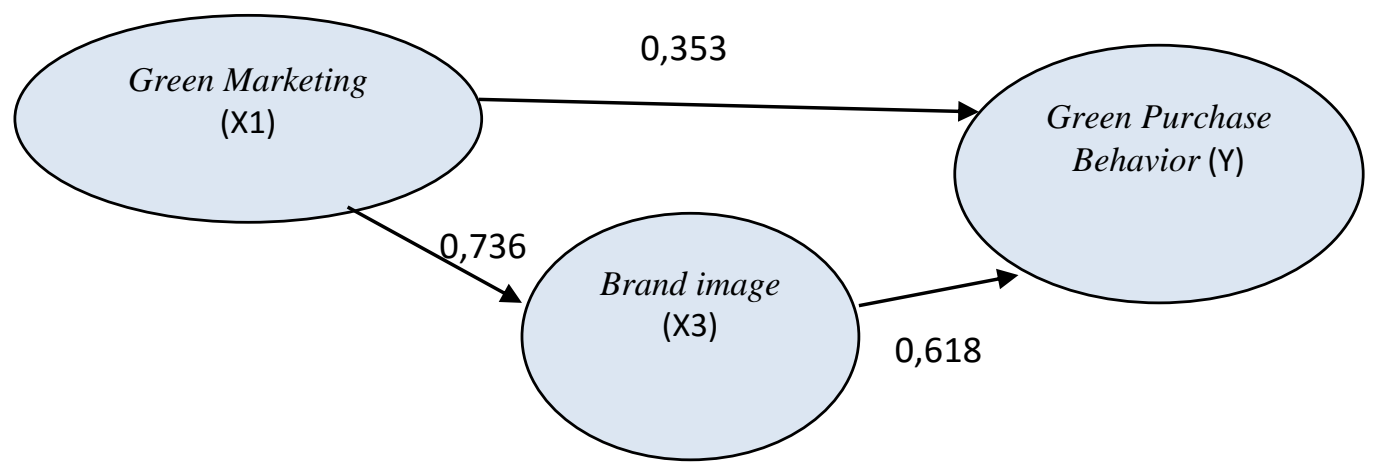

Gambar 2. Analisis jalur pengaruh X1 terhadap Y melalui X3 Data Primer diolah Tahun 2016 


\section{Analisis Pengetahuan Lingkungan sebagai sebagai variabel moderasi dari Pemasaran Hijau terhadap Keputusan Pembelian Produk Hijau}

Berdasarkan pada analisis jalur dari ketiga variabel yang akan diuji (Gambar 3). diketahui bahwa pengaruh langsung pemasaran hijau terhadap keputusan pembelian produk hijau adalah 0,353. Sedangkan pengaruh pemasaran hijau terhadap keputusan pembelian produk hijau melalui pengetahuan lingkungan adalah $0,671 \times 0,667=0,447$. Dalam hal ini pengaruh tidak langsung lebih besar dibandingkan pengaruh langsung sehingga dapat dikatakan bahwa variabel pengetahuan lingkungan dapat meningkatkan pengaruh pemasaran hijau terhadap keputusan pembelian produk hijau, maka pengetahuan lingkungan adalah variabel moderasi dalam hubungan pengaruh pemasaran hijau terhadap keputusan pembelian produk hijau

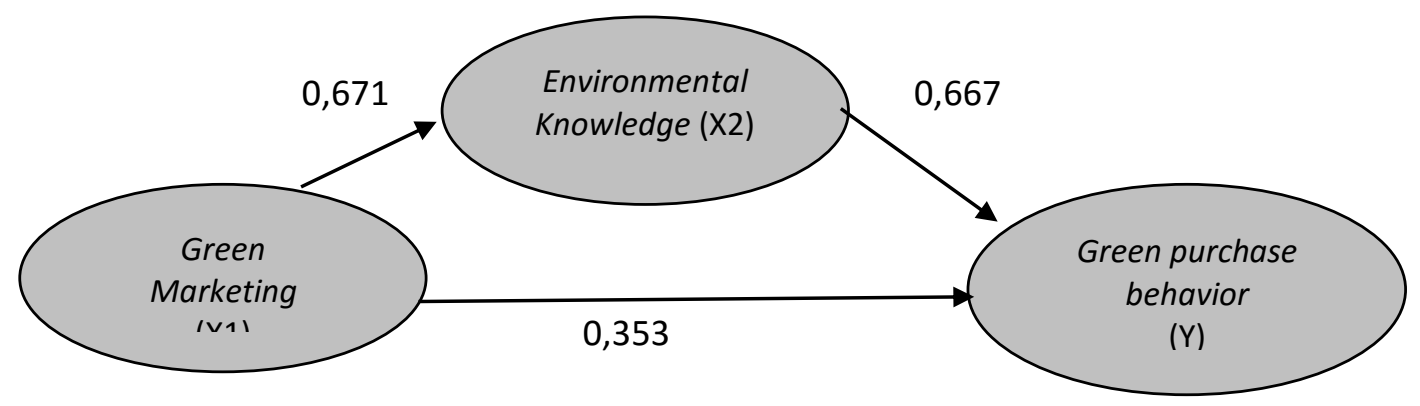

Gambar 3. Analisis jalur pengaruh X2 terhadap Y melalui X3
Data Primer diolah Tahun 2016

\section{KESIMPULAN DAN SARAN}

\section{Kesimpulan}

Berdasarkan hasil olahan data, maka dapat disimpulkan bahwa : 1). Variabel pemasaran hijau memiliki pengaruh yang signifikan terhadap keputusan pembelian produk hijau. Maka dapat disimpulkan bahwa semakin kuat upaya pemasaran hijau dilakukan maka keputusan pembelian terhadap produk hijau juga akan meningkat. 2). Variabel citra merek memiliki pengaruh yang signifikan terhadap keputusan pembelian produk hijau. Maka dapat disimpulkan bahwa semakin kuat citra merek suatu perusahaan maka keputusan pembelian terhadap produk hijau juga akan meningkat.Temuan ini memperkuat hasil penelitian sebelumnya Pujari (2003), pemasaran hijau yang dilakukan oleh produsen berdampak positif bagi perusahaan, diantaranya peningkatan penjualan,meningkatkan kemampuan bersaing perusahaan, memperbaiki atau meningkatkan citra merek atau perusahaan. Hasil temuan Kurniawati (2011) dan Agustin (2009) yang melakukan penelitian tentang pemasaran hijau, mendapatkan hasil bahwa produsen atau perusahaan yang melakukan pemasaran hijau akan sangat berpengaruh terhadap citra merek dan berujung pada keputusan pembelian. 3). Variabel pengetahuan lingkungan memiliki 
pengaruh yang signifikan terhadap keputusan pembelian produk hijau. Maka dapat disimpulkan bahwa semakin masyarakat mengerti tentang lingkungan maka keputusan pembelian terhadap produk hijau juga akan meningkat. Temuan ini memperkuat temuan sebelumnya yaitu hasil penelitian Azizan dan Suki (2013) yang menemukan bahwa pengetahuan lingkungan merupakan faktor yang sangat berpengaruh bagi konsumen untuk melakukan keputusan pembelian produk - produk hijau atau produk ramah lingkungan.

Sedangkan untuk hasil uji variable intervening adalah sebagai berikut: 1). Variabel citra merek dapat meningkatkan pengaruh pemasaran hijau terhadap keputusan pembelian produk hijau, maka citra merek adalah variabel moderasi dalam hubungan pengaruh pemasaran hijau terhadap keputusan pembelian produk hijau,. 2). Variabel pengetahuan lingkungan dapat meningkatkan pengaruh pemasaran hijau terhadap keputusan pembelian produk hijau, maka pengetahuan lingkungan adalah variabel moderasi dalam hubungan pengaruh pemasaran hijau terhadap keputusan pembelian produk hijau,

\section{Saran}

Berdasarkan hasil penelitian, terdapat beberapa saran yang mungkin dapat dijadikan referensi baik bagi pihak perusahaan agar dapat meningkatkan penjualannya, maupun peneliti yang akan datang. Beberapa saran yang dapat disampaikan diantaranya : 1). Peranan pengetahuan masyarakat tentang lingkungan hidup sangat berpengaruh terhadap strategi pemasaran hijau, sehingga dalam penerapan strategi pemasaran hijau pihak perusahan harus memperhatikan dan memberikan edukasi terhadap pihak masyarakat. 2). Strategi pemasaran hijau adalah salah satu strategi yang positif yang dapat diterapkan untuk menciptakan citra merek perusahaan yang positif. 3). Untuk penelitian selanjutnya mungkin dapat ditambahkan beberapa variabel lain yang berpengaruh terhadap keputusan pembelian produk hijau agar hasil penelitian makin beragam

\section{DAFTAR PUSTAKA}

Agustin, Dwi Esti. 2009. Analisis Penerapan Pemasaran Hijau (Green Marketing) untuk Meningkatkan Brand Image Produk Ramah Lingkungan pada Prigel Art \& Gallery Arjosari, Malang. Skripsi tidak Dipublikasikan .

Azizan, Syaidatina Akila Mohamad and Suki Norazah Mohd. 2013. Consumers' Intention to Purchase Green Product: Insights from Malaysia. World Applied Sciences Journal 22 (8): 1129-1134.

Grocery Manufacturers Association (GMA), 2009. Finding the green in today's shoppers: Sustainability trends and new shopper insights. Deloitte Development LLC

Haron, S.A., L. Paim and N. Yahaya, 2005. Towards sustainable consumption: An examination of environmental knowledge among Malaysians. International Journal of Consumer Studies, 29(5): 426436.

Heizer, Jay dan Render, Barry. 2006. Manajemen Operasi (Edisi 7). Salemba Empat, Jakarta.

Kotler.P, and Armstrong.G, Principles of Marketing, Fifth edition, Englewood Cliffs, New York: Prentice-Hall, 1991.

Kotler, Philip dan Kevin Lane Keller. 2009. Manajemen Pemasaran. Alih Bahasa: Bob Sabran, Jilid 1. MM. Jakarta: Erlangga.

Kurniawatai, Ika. 2011. Penerapan Green Marketing Untuk Membentuk Brand Image Pada Upaya 
Membentuk Corporate Image Go Green. Skripsi tidak Dipublikasikan Lampe, Mark, Gregory M. Gazda. 1995. Green Marketing in Europe and the United States: an Evolving Business and Society Interface. International Business Review, Vol 4, No.3.

Mathur, Lynette Knowles. (2000). An Analysis of the Wealth Effects of Green Marketing Strategies. Journal of Business Research, Vol. 50.

Oyewole, Philemon. 2001. Social Costs of Environmental Justice Associated with the Practise of Green Marketing. Journal of Business Ethics, Vol. 29

Paramitra, Yuaniko. and Aruan, Daniel Tumpal. (2017). Let's Playing Game: the Effects of Brand-gameself Congruities on Player's Attitude Towards Brands in Advergames. MIX: Jurnal Ilmiah Manajemen, 7(1). 1-15

Polonsky, Michael Jay, Philip J. Rosenberger III. 2001. Reevaluating Green Marketing: A
Strategic Approach. Business Horizons.

Situmorang, James R. (2011). Pemasaran Hijau Yang Semakin Menjadi Kebutuhan Dalam Dunia Bisnis. Jurnal Administrasi Bisnis (2011), Vol.7, No.2: hal. 131-142, (ISSN:0216-1249) Center for Business Studies. FISIP - Unpar .

Sutisna dan Teddy Pawitra. 2001. Perilaku Konsumen dan Komunikasi Pemasaran. Bandung: PT. Remaja Rosdakarya.

Tjiptono, Fandy. 2005. Pemasaran Jasa. Ed.1. Malang: Banyumedia Publishing.

Willer, H. and L. Kilcher, 2009. The world of organic agriculture: Statistics and emerging trends 2009. IFOAM, DE-Bonn and FiBL, $\mathrm{CH}$-Frick.

http://www.sinarsosro.id/about/corpor ate-profile diakses tanggal 20 Februari 2019.

http://www.kemenperin.go.id/artikel/180 68/Kemenperin-Dorong-ProduksiMobil-Hybrid-dan-Listrik diakses tanggal 25 Februari 2019. 